\title{
Nitrous oxide and carbon dioxide emissions from surface and subsurface drip irrigated tomato fields
}

\begin{abstract}
ABSTRCT
Irrigation practices change the soil moisture in agricultural fields and influence emissions of greenhouse gases (GHG). A 2 yr field study was conducted to assess carbon dioxide (CO2) and nitrous oxide (N2O) emissions from surface and subsurface drip irrigated tomato (Solanum lycopersicum L.) fields on a loamy sand in southern Ontario. Surface and subsurface drip irrigation are common irrigation practices used by tomato growers in southern Ontario. The N2O fluxes were generally $\leq 50 \mu \mathrm{g} \mathrm{N} 2 \mathrm{O}-\mathrm{N} \mathrm{m}^{-2} \mathrm{~h}^{-1}$, with mean cumulative emissions ranging between $352 \pm 83$ and $486 \pm 138 \mathrm{mg} \mathrm{N} 2 \mathrm{O}-\mathrm{N} \mathrm{m}^{-2}$. No significant difference in $\mathrm{N} 2 \mathrm{O}$ emissions between the two drip irrigation practices was found in either study year. Mean $\mathrm{CO} 2$ fluxes ranged from 22 to $160 \mathrm{mg} \mathrm{CO} 2-\mathrm{C} \mathrm{m}^{2} \mathrm{~h}^{-1}$ with cumulative fluxes between $188 \pm 42$ and $306 \pm 31 \mathrm{~g} \mathrm{CO}^{-}-\mathrm{C} \mathrm{m}^{-2}$. Seasonal $\mathrm{CO} 2$ emissions from surface drip irrigation were significantly greater than subsurface drip irrigation in both years, likely attributed to sampling time temperature differences. We conclude that these irrigation methods did not have a direct effect on the GHG emissions from tomato fields in this study. Therefore, both irrigation methods are expected to have similar environmental impacts and are recommended to growers.
\end{abstract}

Keyword: Carbon dioxide; Nitrous oxide; Tomato, Surface drip irrigation; Subsurface drip irrigation. 